\title{
Identifikasi Daerah Resapan Air di Sub Daerah Aliran Sungai Malino Hulu Daerah Aliran Sungai Jeneberang Kabupaten Gowa
}

\author{
Wahyuni ${ }^{1,}$, , Usman Arsyad ${ }^{1}$, Budirman Bachtiar ${ }^{1}$, Muhammad Irfan $^{2}$ \\ ${ }^{1}$ Staf Pengajar Fakultas Kehutanan, Universitas Hasanuddin, Makassar \\ ${ }^{2}$ Kesatuan Pengelolaan Hutan Konservasi (KPHK) Peropa Sulawesi Tenggara \\ Email: uniequ1@gmail.com
}

\begin{abstract}
Population increase encourages people to change land use in Malino sub watershed. The forest area converted into non-forest areas such as agricultural or settlements. This study aims to determine the status and potential of water absorbtion region. This research was conducted in the Malino sub watershed maps using land units derived from overlapping maps of slope, soil type, rainfall and land use. Moreover, the determination of the water absorbtion region refer to the Technical Plan for Forest and Soil rehabilitation - basin. The results showed that up to $27,05 \%$ of the total Malino Sub Watershed is critical condition, normal condition as much as $49,70 \%$ and a good conditions as much as $23.25 \%$. The Malino sub watershed still good potential to absorb water. In natural conditions, the use of land as dry bush agriculture to intervene it is advisable to agroforestry or timber planted with long lasting in order to be a good absorbtion region, while for normal condition advised to planting of agroforestry with pattern alley cropping.
\end{abstract}

Keywords: Malino sub watershed; absorbtion region; potential DOI: http://dx.doi.org/10.24259/jhm.v9i2.2891

\section{PENDAHULUAN}

Kondisi DAS akhir-akhir ini terindikasi semakin menurun karena tingkat kepadatan penduduknya yang sangat tinggi dan pemanfaatan sumberdaya alamnya yang intensif. Meningkatnya kejadian tanah longsor, erosi, sedimentasi, banjir, dan kekeringan merupakan indikator menurunnya daya dukung DAS. Daya dukung DAS terdiri atas daya dukung DAS yang dipertahankan dan daya dukung DAS yang dipulihkan (PP37, 2012).

Salah satu hal yang dipertimbangkan untuk menentukan apakah daya dukung suatu DAS dipertahankan atau dipulihkan adalah kualitas, kuantitas dan kontinuitas air. Kualitas, kuantitas dan kontinuitas air saat ini telah mengalami gangguan disebagian besar wilayah Indonesia. Hal ini dicirikan oleh sungai yang semakin keruh, rasio perbedaan antara debit maksimum dan minimum yang sangat besar dan ketersediaan kebutuhan air setiap tahun tidak terjamin. Kondisi seperti itu oleh Triweko (2014) menyatakan bahwa ketahanan air telah terganggu. Ketahanan air yang dimaksudkan adalah kemampuan masyarakat untuk menjaga keberlanjutan dalam pemenuhan kebutuhan air dalam hal jumlah yang mencukupi. Jumlah penduduk yang semakin bertambah menyebabkan kebutuhan akan lahan juga meningkat, dan ini berdampak pada hutan yang akan diubah menjadi lahan pertanian, dan selanjutnya lahan pertanian akan berubah menjadi permukiman. Perubahan tata guna lahan tersebut pada akhirnya berdampak pada meningkatnya limpasan permukaan, menurunnya kualitas air akibat pencemaran oleh limbah rumah tangga, perkotaan dan industri.

Sebagai suatu kesatuan tata air, DAS dipengaruhi kondisi bagian hulu khususnya kondisi biofisik daerah tangkapan dan daerah resapan air. Daerah masuknya air dari permukaan tanah ke dalam zona jenuh air sehingga membentuk suatu aliran air tanah yang mengalir ke daerah yang lebih rendah disebut daerah resapan air (Wibowo, 2006). Fungsi daerah resapan air adalah untuk menampung air hujan yang turun di daerah tersebut. Secara tidak langsung daerah resapan air memegang peran penting sebagai pengendali banjir pada musim hujan dan kekeringan pada musim kemarau. 
Daerah resapan air semakin berkurang karena adanya alih fungsi lahan di berbagai tempat terutama lahan berhutan. Menurut Arsyad, U (2010) luas daerah berhutan pada hulu DAS Jeneberang tahun 2006 sebesar 13,38\%. Hal ini menggambarkan daerah berhutan telah mengalami perubahan penggunaan lahan dikarenakan jumlah penduduk semakin bertambah yang menyebabkan kebutuhan lahan juga semakin meningkat. Lahan yang dulunya merupakan daerah berhutan atau daerah resapan air diubah fungsinya menjadi daerah tidak berhutan. Akibatnya areal yang dulunya mampu meresapkan air dalam jumlah yang banyak akan menurun karena perubahan penggunaan lahan tersebut. Salah satu cara yang dapat digunakan dalam mengidentifikasi daerah resapan air adalah dengan mengetahui parameter-parameter yang mempengaruhinya. Hastono, dkk (2012) menyatakan bahwa parameter-parameter yang mempengaruhi daerah resapan air adalah jenis tanah atau batuan, curah hujan, kemiringan lereng dan penggunaan lahan.

Sub DAS Malino merupakan salah satu Sub DAS dari DAS Jeneberang yang secara administratif terletak di Kecamatan Tinggi Moncong Kabupaten Gowa yang memiliki luas 8.683 ha atau sekitar 10,96\% dari luas DAS Jeneberang (Kementerian Kehutanan, 2012) dalam (Ashab, 2014). Pertambahan jumlah penduduk akan mendorong masyarakat untuk melakukan alih fungsi lahan yang awalnya hutan menjadi lahan pertanian pada Sub DAS Malino (Ashab, 2014). Wiwoho (2008) menyatakan perubahan penggunaan lahan yang menghasilkan permukaan lahan yang kedap air mengakibatkan air hujan yang jatuh tidak dapat meresap ke dalam tanah. Hujan akan langsung menjadi aliran permukaan, dan meningkatkan potensi banjir dan genangan di kawasan tersebut. Informasi mengenai kondisi dan potensi daerah resapan air di Sub DAS Malino masih sangat kurang. Padahal informasi mengenai hal tersebut dianggap sangat perlu karena dapat dijadikan landasan dalam pengambilan keputusan untuk menentukan daerah resapan air pada wilayah konservasi dan rehabilitasi lahan serta hutan yang diharapkan dapat memperbaiki ketahanan air di Sub DAS Malino. Karena itu dianggap perlu melakukan penelitian untuk mengidentifikasi daerah resapan air di Sub DAS Malino.

\section{METODE PENELITIAN}

\subsection{Waktu dan Tempat}

Penelitian ini telah dilaksanakan selama tiga bulan yaitu mulai Bulan Februari sampai dengan Bulan April 2016 melalui dua tahapan kegiatan yaitu kegiatan lapangan dan analisis data. Kegiatan lapangan dilakukan di Sub Daerah Aliran Sungai Malino sedangkan untuk analisis data dilakukan di Laboratorium Pengelolaan Daerah Aliran Sungai Fakultas Kehutanan Universitas Hasanuddin.

\subsection{Prosedur Penelitian}

Tahap pertama dilakukan delineasi batas Sub DAS Malino dengan menggunakan data dari Aster DEM, kemudian tahap kedua menentukan lokasi penelitian berdasarkan peta jenis tanah, kemiringan lereng, peta penggunaan lahan yang ditumpang susun menghasilkan peta unit lahan, untuk menentukan titik lokasi penelitian. Jumlah unit lahan yang terbentuk sebanyak 20 unit lahan.

Selanjutnya dilakukan pengumpulan data di lapangan, berupa data kelerengan, pengambilan sampel tanah, dan pengamatan laju infiltrasi pada setiap titik pengamatan.

\subsection{Analisis Data}

Analisis data yang dimaksudkan adalah analisis untuk menentukan infiltrasi potensial dan infiltrasi aktual dengan menggunakan metode overlay. Menurut RTkRHL-DAS (2010), infiltrasi potensial dipengaruhi oleh faktor kemiringan lereng, curah hujan dan tanah. Sedangkan untuk infiltrasi 
aktual dipengaruhi oleh penggunaan lahan. Keempat faktor tersebut kemudian disajikan dalam bentuk peta.

\section{a. Kemiringan Lereng}

Peta kemiringan lereng dibuat berdasarkan analisis Aster DEM yang selanjutnya dilakukan klasifikasi menjadi beberapa kelas dan disajikan pada Tabel 1.

Tabel 1. Klasifikasi Kemiringan Lereng dan Penotasiannya

\begin{tabular}{cclccc}
\hline No & Kelas & \multicolumn{1}{c}{ Deskripsi } & Lereng $(\%)$ & Notasi & Skor \\
\hline 1 & I & Datar & $<8$ & A & 5 \\
\hline 2 & II & Landai & $8-15$ & B & 4 \\
\hline 3 & III & Bergelombang & $15-25$ & C & 3 \\
\hline 4 & IV & Curam & $25-40$ & D & 2 \\
\hline 5 & V & Sangat curam & $>40$ & E & 1
\end{tabular}

\section{b. Curah Hujan}

Peta curah hujan yang dioverlay dibuat berdasarkan data curah hujan yang diperoleh dari Global Weather. Data ini diperlukan untuk mengetahui nilai infiltrasi rata-rata per tahun setiap stasiun pengukur curah hujan pada daerah penelitian. Perhitungan infiltrasi rata-rata per tahun dihitung dengan menggunakan rumus Hastono, dkk. (2012), sebagai berikut:

dimana:

$$
\mathrm{RD}=0,01 \times \mathrm{P} \times \mathrm{Hh}
$$

$\mathrm{RD}=$ faktor hujan infiltrasi

$\mathrm{P} \quad=$ curah hujan tahunan (mm/tahun)

$\mathrm{Hh} \quad=$ jumlah hari hujan tiap tahun (berapa hari hujan dalam setiap tahun)

Hasil perhitungan nilai RD tersebut dalam kaitannya dengan potensial infiltrasinya dapat diklasifikasikan seperti disajikan pada Tabel 2.

Tabel 2. Klasifikasi Nilai Hujan Infiltrasi

\begin{tabular}{cclccc}
\hline No & Kelas & \multicolumn{1}{c}{ Deskripsi } & Nilai “hujan infiltrasi” RD & Notasi & Skor \\
& & & & & \\
\hline 1 & I & Rendah & $<2500$ & A & 5 \\
\hline 2 & II & Sedang & $2500-3500$ & B & 4 \\
\hline 3 & III & Agak besar & $3500-4500$ & C & 3 \\
\hline 4 & IV & Besar & $4500-5500$ & D & 2 \\
\hline 5 & V & Sangat besar & $>5500$ & E & 1 \\
\hline
\end{tabular}

c. Tanah

Peta jenis tanah di Sub DAS Malino didasarkan pada pembagian jenis tanah dan diperoleh dari Data sistem lahan (land system) Regional Physical Project for Transmigration (RePPProt) Badan Koordinasi Survey dan Pemetaan Nasional Tahun 1987. Setelah jenis tanah diketahui akan dilakukan pengambilan sampel tanah untuk menghitung permeabilitasnya, dan kemudian melakukan pembobotan pada setiap jenis tanah dalam mengidentifikasi daerah resapan air, yang mengacu pada Tabel 3 . 
Tabel 3. Klasifikasi dan Skor untuk Permeabilitas Tanah

\begin{tabular}{ccllll}
\hline No & Kelas & \multicolumn{1}{c}{ Deskripsi } & \multicolumn{1}{c}{$\begin{array}{c}\text { Permeabilitas } \\
(\mathrm{cm} . j \mathrm{~m})\end{array}$} & Notasi & Skor \\
\hline 1 & I & Cepat & $>12,7$ & $\mathrm{a}$ & 5 \\
\hline 2 & II & Agak cepat & $6.3-12,7$ & $\mathrm{~b}$ & 4 \\
\hline 3 & III & Sedang & $2,0-6,3$ & $\mathrm{C}$ & 3 \\
\hline 4 & IV & Agak lambat & $0,5-2,0$ & $\mathrm{~d}$ & 2 \\
\hline 5 & V & Lambat & $<0,5$ & $\mathrm{e}$ & 1 \\
\hline
\end{tabular}

\section{d. Penggunaan Lahan}

Analisis pada penggunaan lahan didasarkan pada peta penggunaan lahan dari Balai Pemantapan Kawasan Hutan (BPKH) Wilayah VII. Data ini diperlukan untuk mengukur kriteria dan indikator kinerja DAS, untuk klasifikasi penggunaan lahan dan penotasiannya dapat dilihat pada Tabel 4.

Tabel 4. Klasifikasi Penggunaan Lahan

\begin{tabular}{ccllc}
\hline No & Kelas & \multicolumn{1}{c}{ Deskripsi } & \multicolumn{1}{c}{ Tipe Penggunaan Lahan } & Notasi \\
\hline 1 & I & Besar & Hutan lebat & A \\
\hline 2 & II & Agak besar & Hutan produksi, perkebunan & B \\
\hline 3 & III & Sedang & Semak, padang rumput & C \\
\hline 4 & IV & Agak kecil & Hortikultura (landai) & D \\
\hline 5 & V & Kecil & Pemukiman, Sawah & E \\
\hline
\end{tabular}

\section{e. Teknik Klasifikasi Kondisi Daerah Resapan Air}

Peta kemiringan lereng, tanah, curah hujan dan penggunaan lahan dioverlay untuk menghasilkan peta baru yang menggambarkan kondisi daerah resapan. Selain itu, untuk mengidentifikasi kondisi daerah resapan air dilakukan dengan membandingkan antara nilai infiltrasi potensial dengan nilai infiltrasi aktualnya.

Klasifikasi daerah resapan air didasarkan pada Kriteria dan Tata Cara Penyusunan Rencana Teknik Rehabilitasi Hutan dan Lahan Daerah Aliran Sungai (RTkRHL-DAS) tahun 2010, dengan kriteria sebagai berikut:

1. Kondisi Baik, yaitu jika nilai infiltrasi aktual lebih besar dibanding nilai infiltrasi potensial, misalnya dari e menjadi $A$, atau dari d menjadi $B$ dan seterusnya.

2. Kondisi Normal Alami, yaitu jika nilai infiltrasi aktual sama atau tetap seperti nilai infiltrasi potensialnya, misalnya dari $b$ menjadi $B$, atau dari $c$ menjadi $C$ dan seterusnya.

3. Kondisi Mulai Kritis, yaitu jika nilai infiltrasi aktual sudah turun setingkat dari nilai infiltrasi potensialnya, misalnya dari a menjadi $B$, atau dari $c$ menjadi $D$ dan seterusnya.

4. Kondisi Agak Kritis, yaitu jika nilai infiltrasi aktual sudah turun dua tingkat dari nilai infiltrasi potensialnya, misalnya dari a menjadi $\mathrm{C}$, atau dari b menjadi $\mathrm{D}$ dan seterusnya.

5. Kondisi Kritis, yaitu jika nilai infiltrasi aktual sudah turun tiga tingkat dari nilai infiltrasi potensialnya, misalnya dari a menjadi $\mathrm{D}$, atau dari $\mathrm{b}$ menjadi $\mathrm{E}$.

6. Kondisi sangat Kritis, yaitu jika nilai infiltrasi aktual berubah dari sangat besar menjadi sangat kecil, misalnya dari a menjadi $\mathrm{E}$. 
Cara identifikasi kelas kondisi daerah resapan air selengkapnya ditunjukkan pada Gambar1.

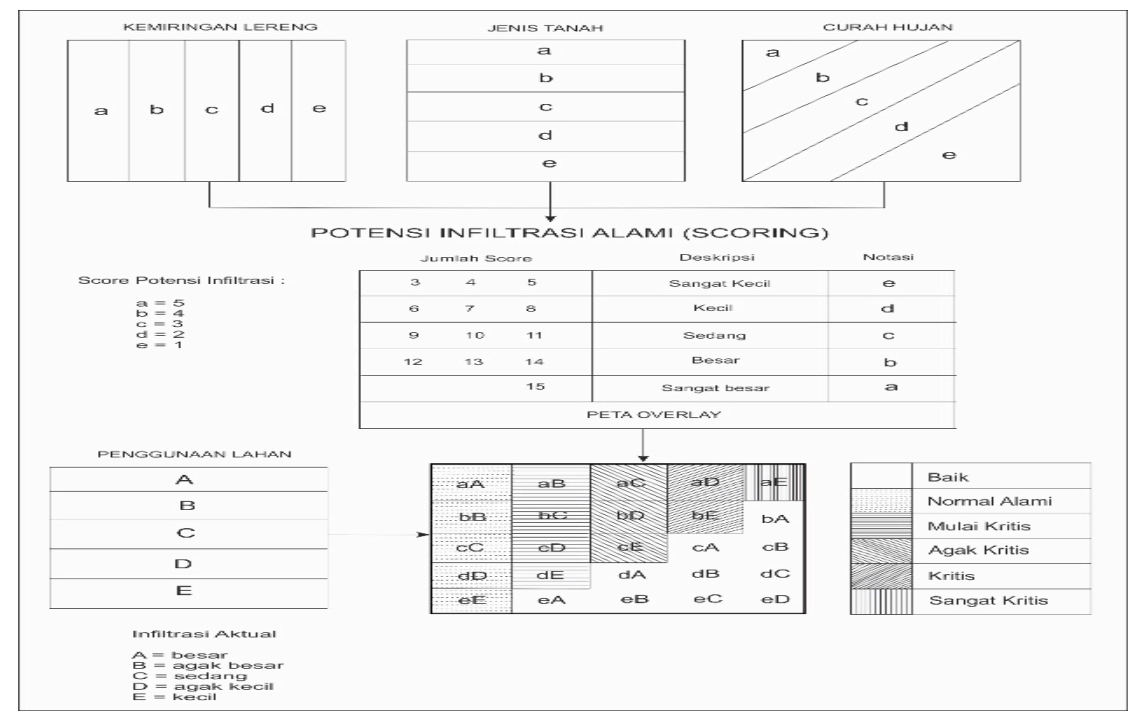

Gambar 1. Garis Besar Pendekatan Penyusunan Model Pengkajian Daerah Resapan Air

\section{HASIL DAN PEMBAHASAN}

\subsection{Infiltrasi Potensial}

\section{a. Kemiringan Lereng}

Hasil analisis peta kemiringan lereng diketahui sebaran kelas kemiringan lereng Sub DAS Malino. Luas area, kelas lereng dan nilai skornya dapat dilihat pada Tabel 5.

Tabel 5. Data Peta Kemiringan Lereng Sub DAS Malino

\begin{tabular}{ccccccr}
\hline No. & Kelas Lereng & Luas (ha) & $\begin{array}{c}\text { Persentase } \\
\text { Luasan (\%) }\end{array}$ & Deskripsi & Notasi & Skor \\
\hline 1 & $0-8 \%$ & 1399,57 & 16,12 & Datar & a & 5 \\
\hline 2 & $8-15 \%$ & 1080,38 & 12,45 & Landai & b & 4 \\
\hline 3 & $15-25 \%$ & 2803,33 & 32,30 & Agak Curam & c & 3 \\
\hline 4 & $25-40 \%$ & 1763,20 & 20,31 & Curam & d & 2 \\
\hline 5 & $>40 \%$ & 1633,40 & 18,82 & Sangat Curam & e & 1 \\
\hline & Total & 8679,88 & 100 & & & \\
\hline
\end{tabular}

Tabel 5 menunjukkan bahwa kondisi topografi di Sub DAS Malino secara umum persentase luasannya yaitu agak curam, curam dan sangat curam ini menyebabkan kurangnya air yang dapat ter infiltrasi, karena sebagian besar air hujan akan menjadi aliran permukaan. Tetapi pada wilayah datar dan landai akan berdampak baik dalam proses infiltrasi, dikarenakan air yang jatuh terlebih dahulu menggenang di atas permukaan tanah dan kemudian akan terinfiltrasi ke dalam tanah.

\section{b. Curah Hujan}

Nilai hujan infiltrasi (RD) rata-rata diperoleh dengan mengumpulkan data curah hujan harian selama 10 tahun (2004-2013) yang diambil dari The National Center of Environment Prediction. Sub DAS Malino terbagi atas dua wilayah stasiun curah hujan. Data curah hujan tersebut kemudian diolah 
untuk mendapatkan nilai hujan infiltrasi (RD) rata-rata dan hasilnya dapat dilihat pada Tabel 6 dan Tabel 7

Tabel 6. Hujan Infiltrasi Tahunan Rata-rata dari Tahun 2004-2013 pada Stasiun 1

\begin{tabular}{|c|c|c|c|c|c|c|c|}
\hline \multicolumn{2}{|c|}{ Koordinat } & \multirow[t]{2}{*}{ Tahun } & \multirow{2}{*}{$\begin{array}{l}\text { Hujan } \\
\text { Infiltrasi }\end{array}$} & \multirow{2}{*}{$\begin{array}{c}\text { Hujan Infiltrasi } \\
\text { Rata-rata (RD) } \\
\text { mm/tahun }\end{array}$} & \multirow[t]{2}{*}{ Keterangan } & \multirow[t]{2}{*}{ Notasi } & \multirow[t]{2}{*}{ Skor } \\
\hline$X$ & Y & & & & & & \\
\hline \multirow{10}{*}{$\begin{array}{c}119 \\
688004\end{array}$} & \multirow[t]{10}{*}{$-5,15178$} & 2004 & 7943,73 & \multirow[t]{10}{*}{7833,345} & \multirow[t]{10}{*}{ sangat besar } & \multirow[t]{10}{*}{$\mathrm{E}$} & \multirow[t]{10}{*}{1} \\
\hline & & 2005 & 9781,56 & & & & \\
\hline & & 2006 & 5753,9 & & & & \\
\hline & & 2007 & 9472,75 & & & & \\
\hline & & 2008 & 8159,19 & & & & \\
\hline & & 2009 & 8649,61 & & & & \\
\hline & & 2010 & 21023,13 & & & & \\
\hline & & 2011 & 2207,76 & & & & \\
\hline & & 2012 & 1689,83 & & & & \\
\hline & & 2013 & 3651,99 & & & & \\
\hline
\end{tabular}

Tabel 7. Hujan Infiltrasi Tahunan Rata-rata dari Tahun 2004-2013 pada Stasiun 2

\begin{tabular}{|c|c|c|c|c|c|}
\hline Koordinat & Tahun & Hujan & Hujan & Keterangan & \multirow[t]{2}{*}{ Notasi } \\
\hline$Y$ & & & $\begin{array}{l}\text { Infiltrasi } \\
\text { Rata-rata }\end{array}$ & & \\
\hline
\end{tabular}

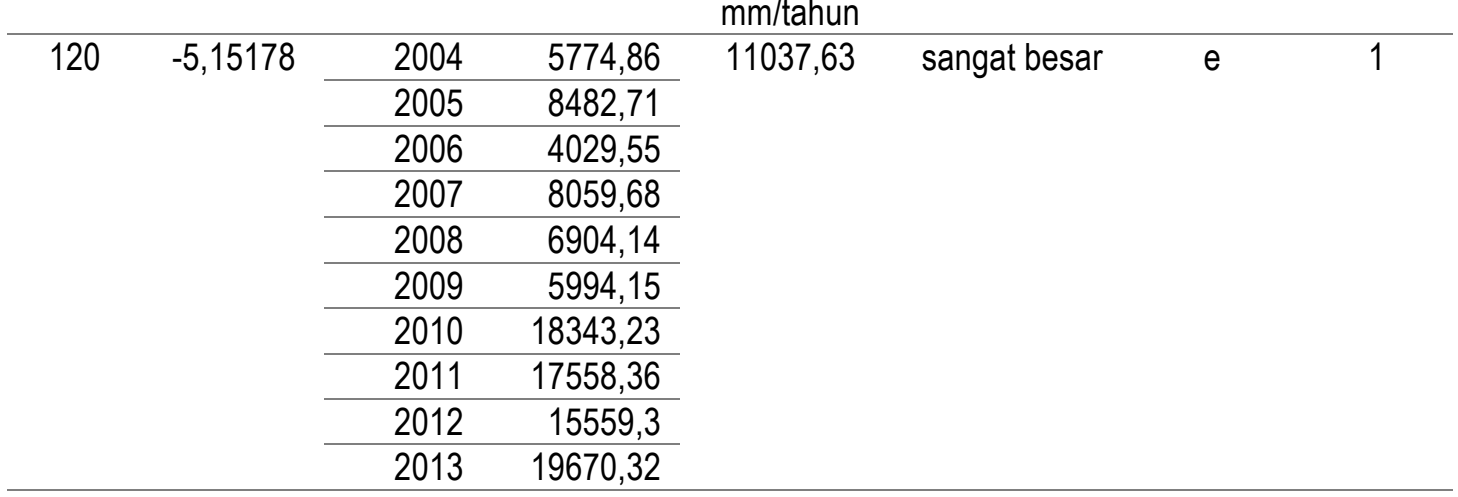

Curah hujan infiltrasi yang terdapat di Sub DAS Malino jika mengacu pada RTkRHL-DAS tahun 2010 termasuk dalam kisaran kondisi sangat besar, yaitu $>5500 \mathrm{~mm}$. Berdasarkan Tabel 6 dan Tabel 7, diketahui bahwa hujan infiltrasi rata-rata (RD) di Sub DAS Malino sebesar 7833,35 dan 11037,63 dengan jumlah hari hujan rata-rata 245 hari/tahun dan 292 hari/tahun. Semakin tinggi dan lama curah hujan, semakin besar skornya karena pada dasarnya semakin banyak air yang dapat meresap ke dalam tanah (Wibowo, 2006).

c. Tanah

Berbagai tipe/jenis tanah mempunyai kepekaan terhadap laju infiltrasi, permeabilitas dan kapasitas menahan air yang berbeda-beda. Sampel tanah yang diambil, dianalisis di laboratorium guna mengetahui tekstur dan permeabilitas tanah pada lokasi penelitian.

Berikut klasifikasi jenis tanah dan laju permeabilitas di wilayah Sub DAS Malino dan notasinya pada Tabel 8. 
Tabel 8. Klasifikasi Jenis Tanah dan Permeabilitas

\begin{tabular}{|c|c|c|c|c|c|c|c|}
\hline $\begin{array}{l}\text { Unit } \\
\text { Lahan }\end{array}$ & $\begin{array}{c}\text { Permeabilita } \\
\mathrm{s}(\mathrm{cm} / \mathrm{jam})\end{array}$ & Deskripsi & $\begin{array}{c}\text { Kelerengan } \\
(\%)\end{array}$ & Tekstur & $\begin{array}{l}\text { Jenis } \\
\text { Tanah }\end{array}$ & $\begin{array}{c}\text { Notas } \\
\mathrm{i}\end{array}$ & $\begin{array}{c}\text { Sko } \\
r\end{array}$ \\
\hline 1 & 4,8 & Sedang & 28,67 & $\begin{array}{l}\text { Lempung liat } \\
\text { berpasir }\end{array}$ & Oxisol & c & 3 \\
\hline 2 & 2,4 & Sedang & 12,27 & $\begin{array}{l}\text { Lempung liat } \\
\text { berpasir }\end{array}$ & Oxisol & $C$ & 3 \\
\hline 3 & 6,5 & Agak Cepat & 40,4 & $\begin{array}{l}\text { Lempung } \\
\text { berpasir }\end{array}$ & Oxisol & $b$ & 4 \\
\hline 4 & 5,3 & Sedang & 42,44 & $\begin{array}{c}\text { Lempung liat } \\
\text { berpasir }\end{array}$ & Inceptisol & c & 3 \\
\hline 5 & 12,5 & Agak Cepat & 44,52 & $\begin{array}{l}\text { Lempung liat } \\
\text { berpasir }\end{array}$ & Inceptisol & b & 4 \\
\hline 6 & 3,2 & Sedang & 24,93 & $\begin{array}{l}\text { Lempung liat } \\
\text { berpasir }\end{array}$ & Inceptisol & C & 3 \\
\hline 7 & 2,3 & Sedang & 32,49 & Liat berpasir & Inceptisol & c & 3 \\
\hline 8 & 1,4 & Agak Lambat & 27,73 & $\begin{array}{l}\text { Lempung } \\
\text { berliat }\end{array}$ & Entisol & d & 2 \\
\hline 9 & 4,5 & Sedang & 7,87 & Lempung & Ultisol & $C$ & 3 \\
\hline 10 & 5,1 & Sedang & 20,34 & Liat & Ultisol & C & 3 \\
\hline 11 & 4,7 & Sedang & 13,16 & $\begin{array}{l}\text { Lempung } \\
\text { berpasir }\end{array}$ & Ultisol & C & 3 \\
\hline 12 & 0,3 & Lambat & 41,42 & $\begin{array}{l}\text { Lempung liat } \\
\text { berpasir }\end{array}$ & Ultisol & e & 1 \\
\hline 13 & 0,2 & Lambat & 19,43 & $\begin{array}{l}\text { Lempung } \\
\text { berpasir }\end{array}$ & Ultisol & e & 1 \\
\hline 14 & 0,9 & Agak Lambat & 5,24 & $\begin{array}{l}\text { Lempung } \\
\text { berliat }\end{array}$ & Alfisol & $d$ & 2 \\
\hline 15 & 9,5 & Agak Cepat & 17,63 & $\begin{array}{l}\text { Lempung } \\
\text { berpasir }\end{array}$ & Alfisol & $b$ & 4 \\
\hline 16 & 8,7 & Agak Cepat & 46,63 & $\begin{array}{l}\text { Lempung liat } \\
\text { berpasir }\end{array}$ & Ultisol & $b$ & 4 \\
\hline 17 & 7,5 & Agak Cepat & 6,99 & Liat & Ultisol & $b$ & 4 \\
\hline 18 & 1,2 & Agak Lambat & 29,62 & $\begin{array}{l}\text { Lempung } \\
\text { berpasir }\end{array}$ & Ultisol & $d$ & 2 \\
\hline 19 & 0,6 & Agak Lambat & 2,62 & $\begin{array}{c}\text { Lempung } \\
\text { berliat }\end{array}$ & Ultisol & $d$ & 2 \\
\hline 20 & 1,8 & Agak Lambat & 31,53 & $\begin{array}{l}\text { Lempung } \\
\text { berpasir }\end{array}$ & Ultisol & $d$ & 2 \\
\hline
\end{tabular}

Tabel 8 menunjukkan bahwa permeabilitas tanah di Sub DAS Malino terdiri atas empat kelas, yaitu agak cepat, sedang, agak lambat dan lambat. Permeabilitas tanah sangat dipengaruhi oleh tekstur tanah dan kelerengan, tanah yang bertekstur kasar mempunyai kapasitas infiltrasi yang tinggi (Utomo (1989) dalam Muhajirin (2015). Pada unit lahan 17 yang tekstur tanahnya liat, permeabilitas agak cepat, ini terjadi karena kelerengan pada unit lahan 17 terdapat pada kelas lereng datar yakni sebesar $6,99 \%$. Sedangkan pada unit lahan 18 yang tekstur tanahnya lempung berpasir, permeabilitas agak lambat, ini disebabkan unit lahan 18 memiliki kelerengan 29,62\% yaitu pada kelas lereng curam. Ini mengindikasikan bahwa faktor yang paling berpengaruh terhadap permeabilitas tanah adalah kelerengan. Menurut Maro'ah (2011) permeabilitas meningkat 
seiring peningkatan laju infiltrasi, ini berarti bahwa permeabilitas berbanding lurus dengan laju infiltrasi.

\subsection{Infiltrasi Aktual}

\section{a. Penggunaan Lahan}

Penggunaan lahan dipengaruhi oleh beberapa faktor, terutama manusia yang memanfaatkan lahan secara berlebihan sehingga dapat menimbulkan gejala-gejala fisik yang tidak diinginkan, misalnya kemunduran produktivitas pertanian yang berkurang, banjir, erosi, berkurangnya kawasan-kawasan resapan dan lain-lain. Karena itu, penggunaan lahan sifatnya dinamis mengikuti perkembangan kehidupan manusia dan budayanya (Sitorus, 1989). Penggunaan lahan sangat mempengaruhi erosi, aliran permukaan dan sedimentasi terutama dalam hal nilai infiltrasi. Nilai "infiltrasi aktual" dari setiap penggunaan lahan tersaji pada klasifikasi penggunaan lahan dan penotasian pada Tabel 9.

Tabel 9. Data Klasifikasi Penggunaan Lahan Sub DAS Malino

\begin{tabular}{clccc}
\hline No. & Klasifikasi Penggunaan Lahan & Luas (ha) & $\begin{array}{c}\text { Persentase } \\
\text { Luasan (\%) }\end{array}$ & Notasi \\
\hline 1 & Hutan Lahan Kering Sekunder & 1099,49 & 12,67 & B \\
\hline 2 & Hutan Tanaman & 64,66 & 0,74 & B \\
\hline 3 & Perkebunan & 178,58 & 2,06 & B \\
\hline 4 & Pertanian Lahan Kering Campur Semak & 5261,01 & 60,61 & D \\
\hline 5 & Semak Belukar & 645,48 & 7,44 & C \\
\hline 6 & Sawah Jumlah & 1430,66 & 16,48 & E \\
\hline & & 8679,88 & 100,00 & \\
\hline
\end{tabular}

Tabel 9, diketahui bahwa yang mendominasi penggunaan lahan di Sub DAS Malino adalah pertanian lahan kering campur semak $(60,61 \%)$ dengan notasi D. Ini menggambarkan bahwa kondisi Sub DAS Malino memiliki infiltrasi aktual yang kurang baik, sehingga air hujan yang jatuh akan sedikit meresap kedalam tanah dan menjadi aliran permukaan. Gambar 2, menunjukkan data penggunaan lahan dalam bentuk diagram batang di Sub DAS Malino

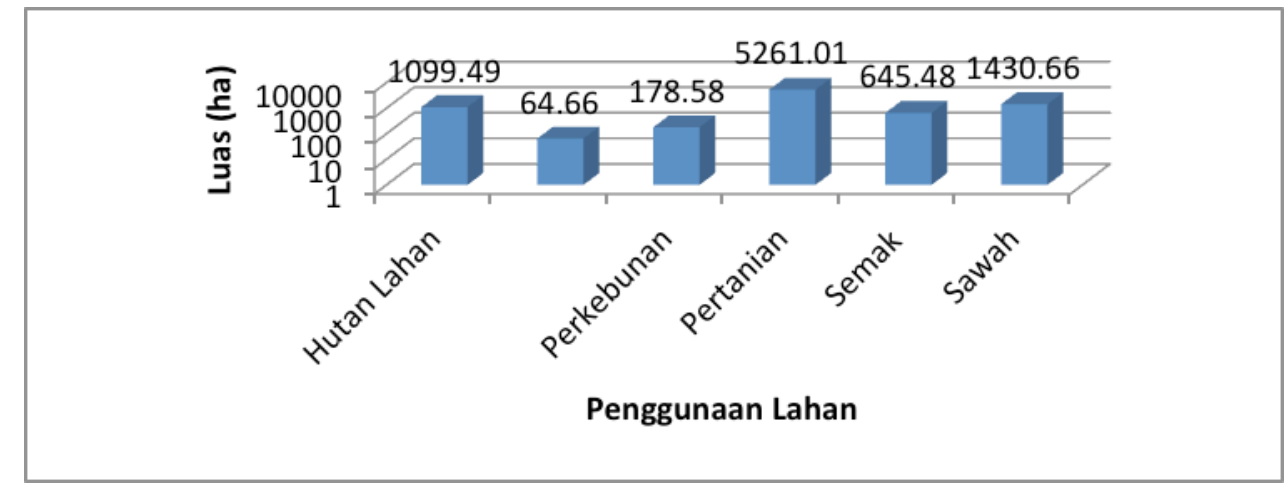

Gambar 2. Diagram Penggunaan Lahan Sub DAS Malino

\subsection{Identifikasi Daerah Resapan Air}

Identifikasi daerah resapan air dilakukan dengan membandingkan infiltrasi potensial dan infiltrasi aktual. Infiltrasi potensial diperoleh dari faktor kemiringan lereng, curah hujan, dan tanah yang nilai-nilainya ditransformasi dan menghasilkan data yang disajikan pada Tabel 10. 
Tabel 10. Infiltrasi Potensial Sub DAS Malino

\begin{tabular}{ccc}
\hline Infiltrasi Potensial & Luas (ha) & Persentase Luasan (\%) \\
\hline Sangat Kecil & 2058,97 & 23,72 \\
\hline Kecil & 6505,68 & 74,95 \\
\hline Sedang & 115,23 & 1,33 \\
\hline Total & 8679,88 & 100 \\
\hline
\end{tabular}

Menurut kriteria dalam RTkRHL-DAS (2010), bentuk penggunaan lahan merupakan aspek di bawah pengaruh kegiatan manusia, mempunyai implikasi yang berbeda terhadap infiltrasi. Jika aspek alami mencerminkan kondisi "potensial", maka aspek penggunaan lahan mencerminkan kondisi "aktual". Dengan cara menumpang tindihkan aspek alami dan aspek aktual (pengaruh manusia), maka dapat dibuat peta hasil overlay yang baru. Peta tersebut disajikan pada Gambar 3 dan data unit lahan pada Tabel 11.

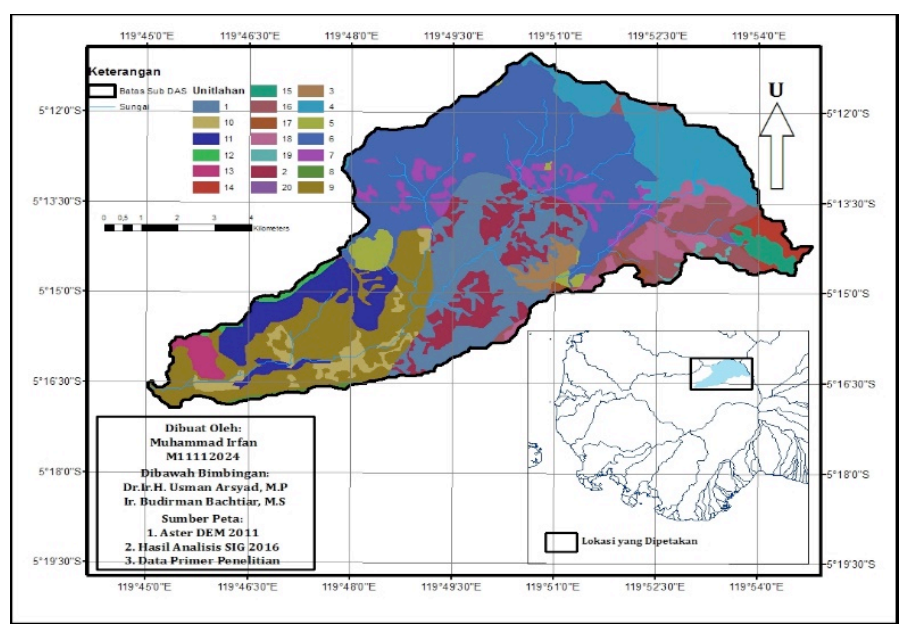

Gambar 3. Peta Unit Lahan Sub DAS Malino

Tabel 11. Data Unit Lahan Sub DAS Malino

\begin{tabular}{|c|c|c|c|c|c|c|c|c|}
\hline \multirow{2}{*}{$\begin{array}{c}\text { Unit } \\
\text { Lahan }\end{array}$} & \multicolumn{4}{|c|}{ Infiltrasi Potensial } & \multicolumn{2}{|l|}{ Infiltrasi Aktual } & \multirow{2}{*}{$\begin{array}{c}\text { Laju } \\
\text { Infiltrasi } \\
\text { (cm/jam) }\end{array}$} & \multirow[t]{2}{*}{ Kondisi } \\
\hline & $\begin{array}{l}\text { Kelerengan } \\
(\%)\end{array}$ & $\begin{array}{l}\text { Curah Hujan } \\
\text { (mm/tahun) }\end{array}$ & $\begin{array}{l}\text { Permeabilitas } \\
\text { (cm/jam) }\end{array}$ & Notasi & Penggunaan Lahan & Notasi & & \\
\hline 1 & 28,67 & 7833,35 & 4,8 & e & $\begin{array}{c}\text { Pertanian Lahan } \\
\text { Kering Campur Semak }\end{array}$ & D & 48,28 & Baik \\
\hline 2 & 12,27 & 7833,35 & 2,4 & $d$ & Sawah & $\mathrm{E}$ & 22,08 & $\begin{array}{l}\text { Mulai } \\
\text { Kritis }\end{array}$ \\
\hline 3 & 40,4 & 11037,63 & 6,5 & e & Semak Belukar & C & 83,04 & Baik \\
\hline 4 & 42,44 & 7833,35 & 5,3 & $d$ & $\begin{array}{l}\text { Hutan Lahan Kering } \\
\text { Sekunder }\end{array}$ & B & 82,36 & Baik \\
\hline 5 & 44,52 & 7833,35 & 12,5 & $d$ & $\begin{array}{l}\text { Hutan Lahan Kering } \\
\text { Sekunder }\end{array}$ & B & 44,28 & Baik \\
\hline 6 & 24,93 & 11037,63 & 3,2 & $d$ & $\begin{array}{c}\text { Pertanian Lahan } \\
\text { Kering Campur Semak }\end{array}$ & D & 22,92 & $\begin{array}{c}\text { Normal } \\
\text { Alami }\end{array}$ \\
\hline 7 & 32,49 & 11037,63 & 2,3 & $d$ & Sawah & $E$ & 19,48 & $\begin{array}{l}\text { Mulai } \\
\text { Kritis }\end{array}$ \\
\hline 8 & 27,73 & 7833,35 & 1,4 & $d$ & $\begin{array}{c}\text { Pertanian Lahan } \\
\text { Kering Campur Semak }\end{array}$ & $\mathrm{D}$ & 14,88 & $\begin{array}{c}\text { Normal } \\
\text { Alami }\end{array}$ \\
\hline 9 & 7,87 & 7833,35 & 4,5 & $d$ & $\begin{array}{c}\text { Pertanian Lahan } \\
\text { Kering Campur Semak }\end{array}$ & D & 24,8 & $\begin{array}{c}\text { Normal } \\
\text { Alami }\end{array}$ \\
\hline 10 & 20,34 & 7833,35 & 5,1 & $d$ & Sawah & $E$ & 59,88 & Mulai \\
\hline
\end{tabular}




\begin{tabular}{ccccccccc}
\hline & & & & & & & Kritis \\
\hline 11 & 13,16 & 7833,35 & 4,7 & $\mathrm{~d}$ & Semak Belukar & $\mathrm{C}$ & 27 & Baik \\
\hline 12 & 41,42 & 7833,35 & 0,3 & $\mathrm{e}$ & Perkebunan & $\mathrm{B}$ & 4 & Baik \\
\hline 13 & 19,43 & 7833,35 & 0,2 & $\mathrm{~d}$ & $\begin{array}{c}\text { Hutan Lahan Kering } \\
\text { Sekunder }\end{array}$ & $\mathrm{B}$ & 3 & Baik \\
\hline 14 & 5,24 & 11037,63 & 0,9 & $\mathrm{C}$ & $\begin{array}{c}\text { Pertanian Lahan } \\
\text { Kering Campur Semak }\end{array}$ & $\mathrm{D}$ & 9,24 & $\begin{array}{c}\text { Mulai } \\
\text { Kritis }\end{array}$ \\
\hline 15 & 17,63 & 11037,63 & 9,5 & $\mathrm{~d}$ & Perkebunan & $\mathrm{B}$ & 66,12 & Baik \\
\hline 16 & 46,63 & 11037,63 & 8,7 & $\mathrm{e}$ & $\begin{array}{c}\text { Pertanian Lahan } \\
\text { Kering Campur Semak }\end{array}$ & $\mathrm{D}$ & 100,52 & Baik \\
\hline 17 & 6,99 & 11037,63 & 7,5 & $\mathrm{~d}$ & Hutan Tanaman & $\mathrm{B}$ & 32,84 & Baik \\
\hline 18 & 29,62 & 11037,63 & 1,2 & $\mathrm{e}$ & Sawah & $\mathrm{E}$ & 11,32 & $\begin{array}{c}\text { Normal } \\
\text { Alami }\end{array}$ \\
\hline 19 & 2,62 & 11037,63 & 0,6 & $\mathrm{~d}$ & Hutan Tanaman & $\mathrm{B}$ & 5,08 & Baik \\
\hline 20 & 31,53 & 11037,63 & 1,8 & $\mathrm{e}$ & Perkebunan & $\mathrm{B}$ & 15,76 & Baik \\
\hline
\end{tabular}

Dari Tabel 11, diketahui bahwa setiap unit lahan memiliki nilai infiltrasi potensial dan infiltrasi aktual yang beragam sehingga menghasilkan kondisi resapan air baik, normal alami, dan mulai kritis. Hasil perbandingan nilai infiltrasi potensial dan nilai infiltrasi aktual diperoleh kombinasi identifikasi resapan air yang terdapat pada Tabel 12.

Tabel 12. Kombinasi Identifikasi Kondisi Daerah Resapan Air di Sub DAS Malino

\begin{tabular}{rll}
\hline No & \multicolumn{1}{c}{ Notasi } & Keterangan \\
\hline 1 & $\mathrm{eB}, \mathrm{eD}, \mathrm{dB}, \mathrm{dC}$ dan $\mathrm{cB}$ & Baik \\
\hline 2 & $\mathrm{eE}$ dan $\mathrm{dD}$ & Normal Alami \\
\hline 3 & $\mathrm{dE}$ dan $\mathrm{cD}$ & Mulai Kritis \\
\hline
\end{tabular}

Identifikasi kondisi daerah resapan air Sub DAS Malino dari kombinasi pada Tabel 12 menghasilkan peta kondisi daerah resapan air dapat dilihat pada Gambar 4.

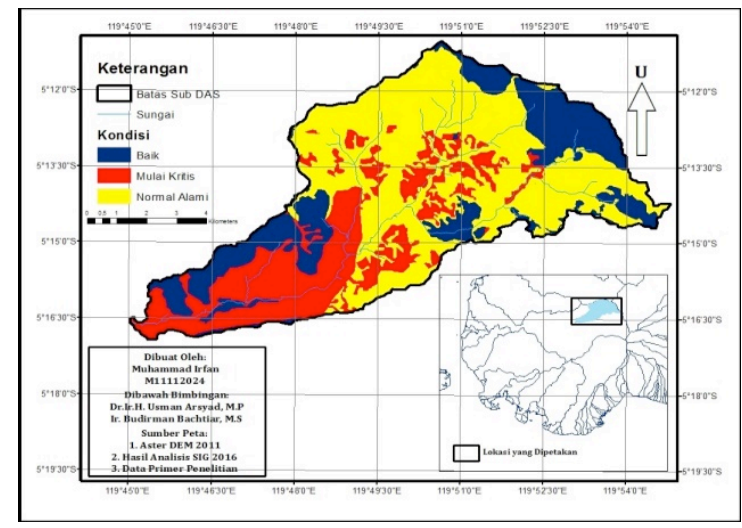

Gambar 4. Peta Daerah Resapan Air Sub DAS Malino

Gambar 4, menunjukkan bahwa kondisi normal alami adalah kondisi yang mendominasi daerah resapan air di Sub DAS Malino. Hasil perhitungan kondisi daerah resapan air dalam cakupan Sub DAS Malino ditunjukkan dalam Tabel 13. 
Tabel 13. Luas Area dan Persentase Luasan Resapan Air Sub DAS Malino

\begin{tabular}{cccc}
\hline No & Luas Area (ha) & Persentase Luasan $(\%)$ & Kriteria \\
\hline 1 & 2018,08 & 23,25 & Kondisi Baik \\
\hline 2 & 4314,22 & 49,70 & Kondisi Normal Alami \\
\hline 3 & 2347,58 & 27,05 & Kondisi Mulai Kritis \\
\hline Total & 8679,88 & 100,00 & \\
\hline
\end{tabular}

Berdasarkan hasil analisis spasial wilayah Sub DAS Malino diketahui bahwa wilayah yang mendominasi adalah kondisi daerah resapan normal alami seluas 4.314,22 ha $(49,70 \%)$. Data ini mengindikasikan bahwa Sub DAS Malino masih dalam kondisi normal sebagai daerah resapan air.

Diketahui bahwa daerah resapan air dipengaruhi oleh faktor curah hujan, kemiringan lereng, permeabilitas tanah dan penggunaan lahan. Keempat faktor ini memiliki pengaruhnya masing-masing dalam menentukan kondisi daerah resapan air. Berikut dijelaskan kondisi daerah resapan air di Sub DAS Malino yang diketahui berdasarkan empat faktor tersebut:

1. Kondisi Daerah Resapan Baik

Daerah dengan kondisi resapan baik yang memiliki luas sebesar 2.018,08 ha atau $23,25 \%$ dari total luas Sub DAS Malino. Termasuk dalam intensitas curah hujan sangat besar, menempati seluruh kelas lereng mulai dari kelas lereng datar sampai sangat curam. Permeabilitas tanah mulai dari lambat sampai agak cepat dengan nilai laju infiltrasi $82,36 \mathrm{~cm} / \mathrm{jam}$. Sedangkan, untuk penggunaan lahannya berupa Pertanian lahan kering campur semak, hutan lahan kering sekunder, hutan tanaman, semak belukar dan perkebunan.

2. Kondisi Daerah Resapan Normal Alami

Daerah dengan kondisi resapan normal alami memiliki luas sebesar $4.314,22$ ha atau $49,70 \%$ dari total luas Sub DAS Malino. Termasuk dalam intensitas curah hujan sangat besar. Kondisi daerah resapan ini menempati kelas lereng datar sampai curam. Terdapat permeabilitas tanah agak lambat, sedang dan agak cepat dengan laju infiltrasi $24,8 \mathrm{~cm} / j a m$. Sedangkan untuk penggunaan lahannya berupa pertanian lahan kering campur semak dan sawah.

3. Kondisi Daerah Resapan Mulai Kritis

Daerah dengan kondisi resapan mulai kritis memiliki luasan sebesar $2.347,58$ ha atau $27,05 \%$ dari total luas Sub DAS Malino. Termasuk dalam intensitas curah hujan sangat besar. Kondisi daerah resapan ini menempati kelas datar, agak curam dan curam. Permeabilitas tanah termasuk dalam kategori sedang dengan laju infiltrasi sebesar 22,08 cm/jam. Sedangkan untuk penggunaan lahannya berupa sawah dan pertanian lahan kering.

Tipe penggunaan lahan berupa pertanian lahan kering campur semak pada kondisi mulai kritis, dapat dilakukan kegiatan agroforestry ataupun hutan rakyat. Untuk penggunaan lahan berupa sawah dapat dilakukan pola agroforestry alley cropping.

\section{KESIMPULAN DAN SARAN}

\subsection{Kesimpulan}

Berdasarkan hasil penelitian yang diperoleh maka dapat ditarik kesimpulan bahwa:

a. Kondisi daerah resapan air di Sub DAS Malino secara umum dalam keadaan baik dengan klasifikasi kondisi baik sebesar 2.018,08 ha $(23,25 \%)$, kondisi normal alami sebesar 4.314,22 ha $(49,70 \%)$ dan kondisi mulai kritis sebesar $2.347,58$ ha $(27,05 \%)$.

b. Potensi kawasan resapan air dalam area penelitian di kawasan Sub DAS Malino umumnya dalam keadaan baik dan normal alami dengan luas keduanya sebesar $6.332,30$ ha atau $72,95 \%$ dari total luas lokasi penelitian. 


\section{尚}

\subsection{Saran}

Peneliti menyarankan kepada peneliti selanjutnya untuk memperhatikan kondisi cuaca sebelum pengukuran laju infiltrasi dan mengamati kondisi tutupan/tanaman bawah di lapangan (di lokasi pengamatan).

\section{DAFTAR PUSTAKA}

Arsyad, U. 2010. Analisis Erosi Pada Berbagai Tipe Penggunaan Lahan dan Kemiringan Lereng di Daerah Aliran Sungai Jeneberang Hulu. Disertasi. Universitas Hasanuddin. Makassar.

Ashab, T. 2014. Evaluasi Kesesuaian Penggunaan Lahan Berdasarkan Kelas Kemampuan Lahan Pada Sub DAS Malino DAS Jeneberang. Skripsi. Universitas Hasanuddin. Makassar.

Hastono, F. D., Bambang Sudarsono dan Bandi Sasmito. 2012. Identifikasi Daerah Resapan Air Dengan Sistem Informasi Geografis (Studi Kasus: Sub DAS Keduang). Universitas Diponegoro. Semarang.

Maro'ah, S. 2011. Kajian Laju Infiltrasi dan Permeabilitas Tanah Pada Beberapa Model Tanaman (Studi Kasus: Sub DAS Keduang, Wonogiri). Skripsi. Universitas Sebelas Maret. Surakarta.

Menteri Kehutanan. 2010. Tata Cara Penyusunan Rencana Teknik Rehabilitasi Hutan dan Lahan Daerah Aliran Sungai. Kementerian Kehutanan RI. Jakarta.

Muhajirin. 2015. Klasifikasi Kondisi Daerah Resapan Air di Daerah Aliran Sungai (DAS) Bonto Saile Kabupaten Kepulauan Selayar. Skripsi. Universitas Hasanuddin. Makassar.

Peraturan Pemerintah Republik Indonesia. 2012. PP Nomor 37 Tentang Pengelolaan Daerah Aliran Sungai. Jakarta.

Sitorus, S.R.P. 1989. Survai Tanah dan Penggunaan Lahan. Laboratorium Perencanaan Sumberdaya Lahan Jurusan IImu Tanah Fakultas Pertanian Institut Pertanian Bogor. Bogor.

Triweko, R.W. 2014. Ketahanan Air Untuk Indonesia: Pandangan Akademisi. www.indonesiawlw.com. diakses tanggal 20 Januari 2016.

Wibowo, M. 2006. Model Penentuan Kawasan Resapan Air Untuk Perencanaan Tata Ruang Berwawasan Lingkungan. Jurnal Hidrosfer, Vol 1, No 1 Hal 1-7. Jakarta.

Wiwoho, B.S. 2008. Analisis Potensi Daerah Resapan Air Hujan di Sub DAS Metro Malang Jawa Timur. Jurusan Geografi FMIPA Universitas Negeri Malang. Surabaya. 